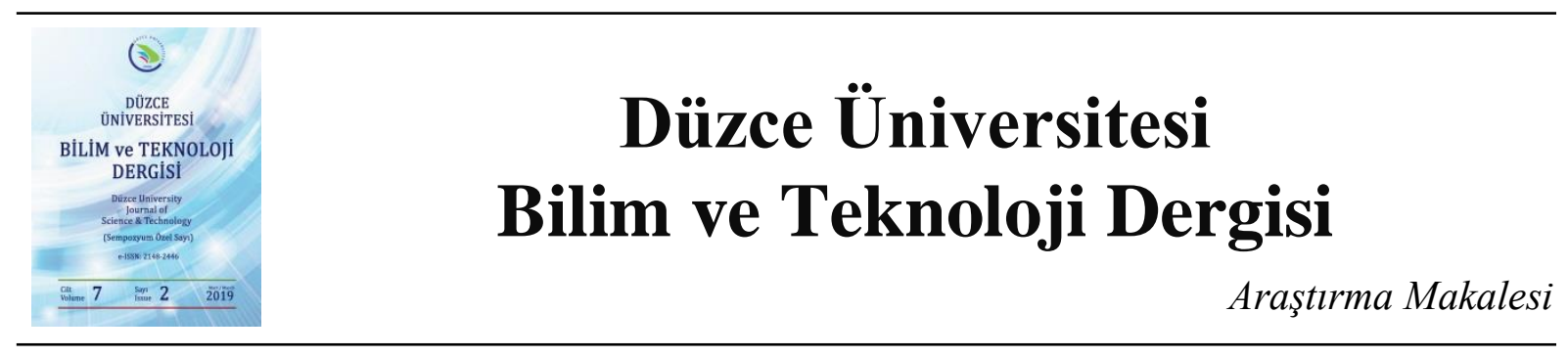

\title{
Konya Gürültü Kirliliği ve Eylem Planlarının Yorumlanması
}

\author{
Emre DALKILIÇ a, ${ }^{*}$, Şükrü DURSUN \\ ${ }^{a}$ Çevre Mühendisliği Bölümü, Mühendislik ve Doğa Bilimleri Fakültesi, Konya Teknik Üniversitesi, Konya, \\ TÜRKIYE \\ *Sorumlu yazar: emredalkilic95@gmail.com
}

\begin{abstract}
ÖZET
İnsanoğlunun hayatında huzurun değeri hiçbir varlıkla değiş̧tirilemeyecek kadar yüksektir. Ancak dünyamızdaki hızlı nüfus artışı, teknolojik gelişmeler, sanayileşme ve trafikteki araç sayısının artışı gibi birçok faktör pek çok sorunu beraberinde getirmektedir. Gürültü: çevresel kaliteyi, hoş görüntüyü ve insan sağlığını olumsuz yönde etkileyen önemli bir sorundur. Gürültüyü hoşa gitmeyen ses veya var olan doğal sesin kirlenmiş hali olarak tanımlanabilmektedir. Özellikle büyük kentlerimizdeki gürültü, çağımızın hastalığı olan stres başta olmak üzere insan yaşamını ve doğal hayatı etkileyerek, kentlerimizi yaşanmaz hale getirmekte ve toplumsal sorunlar açı̆̆a çıkmaktadır. Bu çalışmada Konya'da Konya Büyükşehir Belediyesi tarafindan yapılan uzun süreli ölçüm, izleme ve değerlendirme sonucunda oluşturulan eylem planları uygulama çalışmalarının gürültü kirliliği üzerindeki sonuçlarının değerlendirilmesi yapılmıştır. Kentte eğlence mekânları civarındaki gürültünün kontrolünün gerektiği, trafikte yeşil şerit uygulamaları, raylı sistem ve demiryolu hattında yapılan iyileştirmeler değerlendirilmiş, mevcut iyileştirmelerin problemin çözümünde yeterli olmadığı görülmüştür. Eylem planları uygulama mevcut azaltıcı ve önleyici faaliyetlerin kent gürültü kirliliği üzerine olası etkileri değerlendirilmiştir. Eğlence yerleri, trafik, raylı sistemler ve sanayi kaynaklı gürültü kirliliğinin azaltılması ve önlenmesini içeren Gürülttü Haritaları ve Maruziyet Analizleri yorumlanmıştır. Bu çalışma sonrasında Çevresel Gürültü Eylem Planı kapsamında; Konya Kent Merkezine (Meram, Karatay, Selçuklu ilçeleri) ait topoğrafik haritalar ile birlikte modellenmesi, her bir gürültü kaynağına ilişkin (Eğlence yerleri, Raylı sistem ve demiryolu, endüstri ve trafikten kaynaklı) gürültü haritaları yorumlanmıştır.
\end{abstract}

Anahtar Kelimeler: Gürültü, Çevresel Gürültü̈ Kirliliği, Eylem Planı, Konya

\section{Interpretation of Konya Noise Pollution and Action Plans}

\begin{abstract}
The serenity value for the life of human beings is so high that it cannot be replaced by any beings. However, many factors, such as the rapid population growth in our world, technological developments, industrialization and increase of the vehicles number in traffic, bring many problems. Noise: environmental quality, pleasant appearance and an important problem affecting human health negatively. We can define the noise as unpleasant sound or polluted state of the natural sound that exists. Especially, the noise in metropolitan cities affects human life and natural life, especially the stress that is the disease of our age, making our cities uninhabitable and
\end{abstract}


revealing social problems. In this study, the results of the implementation of action plans prepared by Konya Metropolitan Municipality as a result of long-term measurement, monitoring and evaluation were performed. Noise control around entertainment venues in the city is required, green lane applications in traffic, rail system, and rail line improvements were evaluated, the existing improvements were not enough to solve the problem. Implementation of action plans assess possible impacts on urban noise pollution of existing mitigation and preventive actions. Noise Maps and Exposure Analyses have been interpreted, including the reduction and prevention of entertainment venues, traffic, rail systems and industrial noise pollution. Within the context of the Environmental Noise Action Plan, the topographical maps of Konya City Centre (Meram, Karatay, Selçuklu districts) and the noise maps of each noise source (entertainment places, railway system and railway, industry and traffic) are interpreted.

Keywords: Noise, Environmental Noise Pollution, Action Plan, Konya 